\title{
Phytochemical analysis, in-vitro anti- proliferative, anti-oxidant, anti-diabetic, and anti-obesity activities of Rumex rothschildianus Aarons. extracts
}

Nidal Jaradat*, Mohammed Hawash* (1) and Gada Dass

\begin{abstract}
Background: Rumex rothschildianus is the sole member of a unique section of the genus Rumex, in the family Polygonaceae. This species is a very rare small dioecious annual, endemic to Palestine that is traditionally used as food and for the treatment of various diseases. Therefore, the current investigation aimed to screen the chemical constituents, antioxidants, anti-a-amylase, anti-a-glucosidase, antilipase, and cytotoxic effects of four solvents fractions of $R$. rothschildianus leaves.
\end{abstract}

Methods: Dried powder of $R$. rothschildianus leaves was extracted in four solvents with different polarities. Several qualitative and quantitative phytochemical tests were performed to determine the components of the extracts. The colorimetric analysis was used for the quantitative determination of phenols, flavonoids, and tannins. In-vitro assays were performed to evaluate the extracts for antioxidant, anti-a-amylase, anti-a-glucosidase, and antilipase inhibitory activities, as well as cytotoxicity by MTS assay against cervical carcinoma cells line (HeLa) and breast cancer cell line (MCF7).

Results: The acetone fraction of $R$. rothschildianus leaves showed the most significant antioxidant activity, due to having the highest content of flavonoids and phenolics, with an $I C_{50}$ value of $6.3 \pm 0.4 \mu \mathrm{g} / \mathrm{ml}$, compared to $3.1 \pm$ $0.9 \mu \mathrm{g} / \mathrm{ml}$ for Trolox, and regarding lipase inhibition activity the acetone fraction showed the most potent activity with an $I C_{50}$ value of $26.3 \pm 0.6 \mu \mathrm{g} / \mathrm{ml}$, in comparison with orlistat positive control $I_{50} 12.3 \mu \mathrm{g} / \mathrm{ml}$. The same extract was the most potent inhibitor of a-amylase and a-glucosidase, with $\mathrm{IC}_{50}$ values of $19.1 \pm 0.7 \mu \mathrm{g} / \mathrm{ml}$ and $54.9 \pm$ $0.3 \mu \mathrm{g} / \mathrm{ml}$, respectively, compared to $28.8,37.1 \pm 0.3 \mu \mathrm{g} / \mathrm{ml}$ of acarbose, respectively. The hexane fraction showed 99.9\% inhibition of HeLa cells and $97.4 \%$ inhibition for MCF7 cells.

Conclusion: The acetone fraction of $R$. rothschildianus leaves might provide a source of bioactive compounds for the treatment of oxidative stress. Similarly, the hexane fraction indicates the promising antitumor potential of $R$. rothschildianus. Clearly, these initial indications need further purification of potentially active compounds, and ultimately, in-vivo studies to determine their effectiveness.

Keywords: Rumex rothschildianus, Antioxidant, Lipase, Amylase, Trolox, Phytochemistry, Anti-proliferative activity

* Correspondence: nidaljaradat@najah.edu; mohawash@najah.edu

Department of Pharmacy, Faculty of Medicine and Health Sciences, An-Najah National University, Nablus 00970, Palestine

(c) The Author(s). 2021 Open Access This article is licensed under a Creative Commons Attribution 4.0 International License, which permits use, sharing, adaptation, distribution and reproduction in any medium or format, as long as you give appropriate credit to the original author(s) and the source, provide a link to the Creative Commons licence, and indicate if changes were made. The images or other third party material in this article are included in the article's Creative Commons licence, unless indicated otherwise in a credit line to the material. If material is not included in the article's Creative Commons licence and your intended use is not permitted by statutory regulation or exceeds the permitted use, you will need to obtain permission directly from the copyright holder. To view a copy of this licence, visit http://creativecommons.org/licenses/by/4.0/ The Creative Commons Public Domain Dedication waiver (http://creativecommons.org/publicdomain/zero/1.0/) applies to the data made available in this article, unless otherwise stated in a credit line to the data. 


\section{Background}

Plants have been used as therapies since ancient times. Roots, seeds, bark, leaves, and flowers have all been used for remedial purposes. In the present day, synthetic medicines are available and are effective in the treatment of a wide range of diseases; however, some people still prefer herbal medicines as they are viewed as being less harmful to the human body $[1,2]$. Medicinal plants are by definition the source of phytochemical compounds that possess therapeutic activities. These properties rely upon the presence of different secondary metabolites, such as phenolic, terpenoids, and alkaloids [3].

Rumex rothschildianus Aarons. is the sole member of a unique section of the genus Rumex, in the family Polygonaceae. This species is a very rare small dioeciously annual, endemic in Palestine. It has a mean height of 45 $\mathrm{cm}$, is characterized by erect stems holding radical petiolate leaves, which are short-hastate at the base and short-acuminate at the apex. Flowers have a diameter of $3-4 \mathrm{~mm}$, while pistillate flowers are about $2 \mathrm{~mm}$ in diameter with a coriaceous membranous layer [4]. Rumex spp. are widespread in different regions of Turkey, are represented by 22 species. Some of the most common species are $R$. patientia L., $R$. crispus L., $R$. acetosa L. R. caucasicus rech., and $R$. alpinus L. $R$. alpi$n u s$ and $R$. caucasicus are perennial plants distributed in middle and eastern Anatolia at an altitude of 1000-3000 $\mathrm{m}$ above sea level. The Rumex genus has been widely used in traditional medicine in Turkey to treat disorders, such as constipation, diarrhea, and eczema $[5,6]$. The genus also has some laxative, diuretic, antipyretic, wound healing, and anti-inflammatory effects. Many people in the eastern part of Turkey use young leaves of Rumex spp. as a preservative in cheese, as well as giving food aroma [7].

A variety of research has been carried out on Rumex species, such as antimicrobial activities being reported for some species. Some bioactive phytochemicals have previously been found in Rumex vesicarius L., such as carotenoids, tocopherols, polyphenols, flavonoids, and ascorbic acid, which have a role as antioxidants and natural detoxifying agents. The dietary intake of antioxidant phytochemicals, like carotenoids, phenolics, and flavonoids may protect against non-communicable diseases in humans, such as cancer, cardiovascular disorders, and other health problems related to oxidative stress $[5,8]$.

Harmful free radicals are known to play an important role in many major health problems, such as cancer, cardiovascular disease, rheumatoid arthritis, cataracts, and Alzheimer's disease, and other degenerative diseases related to aging. Antioxidants are beneficial components that neutralize these free radicals before they can attack cells, and hence they prevent damage to cell proteins, lipids, and carbohydrates. A variety of both natural and synthetic antioxidants have been proposed for the treatment of human diseases. Such interest in the role of antioxidants in human health has prompted research in the fields of food science and medicinal herbs, assessing the function of herbs as antioxidants. Antioxidant action includes free radical scavenging capacity, inhibition of lipid peroxidation, metal ion chelating ability and also reducing capacity $[9,10]$.

Cancer is one of the most global health care problems. The development and discovery of novel anticancer medication remain extremely important due to various factors. These factors include treatments that may cause major side effects or can be rather expensive. Alternatives that are safer biologically and more affordable are still highly desirable [11-14].

Several plant species are considered potential sources of bioactive molecules such as atropine from Belladonna leaves, cocaine from coca leaves, vincristine from Vinca plant, and many others which still play an important role in modern medicine $[15,16]$.

Useful therapeutic effects can come from mixing secondary products present in medicinal plants. These compounds are mostly secondary metabolites, like alkaloids, steroids, tannins, flavonoids, and phenolic, which are synthesized and deposited in specific parts of these plants $[17,18]$. The present study investigates the invitro anti- $\alpha$-amylase, anti- $\alpha$-glucosidase, anti-lipase, antiproliferative and antioxidant activities of different fractions extracted from $R$. rothschildianus leaves.

\section{Methods}

\section{Plant material, chemicals, and instruments}

$R$. rothschildianus leaves were harvested from Western regions of Palestine, between February and March 2018. They were identified by Dr. Nidal Jaradat, from the Pharmacognosy Laboratory at An-Najah National University, under the voucher specimen code Pharm-PCT-2066. All chemicals were purchased from Sigma-Aldrich. A spectrophotometer-UV/Visible (Jenway ${ }^{\bullet} 7135$, Staffordshire, UK), filter papers (Whitman No. 1, Washington, USA), shaker device (Memmert 531-25-1, Stockholm, Sweden), rotavap apparatus (Heidolph-VV 2000, Schwabach, Germany), grinder (Aero Plus 500 W Mixer Grinder, I01, Wan Chai, China), electronic-balance (Radwag, AS 220/c/2, Toruńska, Poland), freeze dryer - BT85 (Millrock Technology, China) and cryo-desiccator (Mill-rock technology, BT85, Kingston, USA) were used.

\section{Preparation of extracts and fractionation}

Dried powder of $R$. rothschildianus leaves was extracted by adding solvents sequentially based on their polarity, beginning with the non-polar solvent hexane, and then acetone (a polar aprotic organic solvent), methanol (polar alcohol), and finally distilled water (a polar protic 
solvent). For each extraction, about $25 \mathrm{~g}$ ground dried leaves were placed in 0.51 hexane for $72 \mathrm{~h}$ in a shaker device at 100 rotations per minute at $25^{\circ} \mathrm{C}$. Firstly, the hexane was replaced with $0.5 \mathrm{~L}$ acetone, and then subsequently replacement involved equivalent volumes of methanol and water. Incubations in the solvents were as described above for hexane. Each organic fraction was filtered and concentrated under a vacuum on a rotary evaporator, while the aqueous fraction was dried using a freeze dryer. Finally, all crude fractions were stored at $4{ }^{\circ} \mathrm{C}[19,20]$.

The yield of each fraction was calculated using the following formula:

$$
\begin{aligned}
\text { Yield } \%= & (\text { weight of Rumex extract/original dry } \\
& \text { weight of Rumex leaf tissue }) \times 100 \%
\end{aligned}
$$

\section{Preliminary phytochemical assessment}

Phytochemical screening tests of $R$. rothschildianus leaves four fractions were carried out to identify active secondary metabolites. The qualitative results were expressed as $(+)$ for the presence and (-) for the absence of bioactive phytochemicals [10, 21].

\section{Determination of total phenolic content (TPC)}

The procedure to determine TPC was based on that of Cheung et al. TPC was expressed in milligram of gallic acid equivalents per gram dry weight of leaves (mg GA/g dry weight). Freshly prepared $7.5 \%$ sodium carbonate solution was made by placing $7.5 \mathrm{~g} \mathrm{Na}_{2} \mathrm{CO}_{3}$ in a volumetric flask and adjusting the volume to $100 \mathrm{ml}$ with distilled water. A standard reference solution (gallic acid solution) was prepared by dissolving $100 \mathrm{mg}$ of gallic acid in distilled water to a final volume of $100 \mathrm{ml}$. From this, a serial dilution was performed to obtain solutions of gallic acid at 100, 70, 50, 40, and $10 \mu \mathrm{g} / \mathrm{ml}$ ). The stock solutions of the fractions from leaves were prepared by dissolving $100 \mathrm{mg}$ plant extract in distilled water, adjusted to a total volume of $100 \mathrm{ml}$. Reaction mixtures were prepared by mixing $0.5 \mathrm{ml}$ of each fraction solution with $2.5 \mathrm{ml} 10 \%$ Folin-Ciocalteu's reagent, which was dissolved in water with $2.5 \mathrm{ml} 7.5 \%$ sodium bicarbonate. The sample tubes were incubated for $45 \mathrm{~min}$ at $45^{\circ} \mathrm{C}$. Then, the absorbance of each was measured in a spectrophotometer at wavelength $765 \mathrm{~nm}$. The working samples were prepared in triplicate for each analytic trial, from which the mean and standard deviation values were calculated [21].

\section{Determination of total flavonoid content (TFC)}

The TFC in the four $R$. rothschildianus leaf fractions was assessed using a calibration curve of rutin (standard reference compound). Results were expressed as milligram of rutin equivalent per gram dry weight of leaves extract (mg RU/g dry weight). A calibration curve for rutin was established using serial dilutions generated from a stock solution of $100 \mu \mathrm{g} / \mathrm{ml}$. To make the stock solution, 10 $\mathrm{mg}$ of rutin was dissolved in $10 \mathrm{ml}$ of distilled water and then diluted to $100 \mathrm{ml}$. Subsequently, the stock solution was diluted to provide rutin at concentrations of 10, 30, $40,50,70$, and $100 \mu \mathrm{g} / \mathrm{ml}$. For working solution preparation, $0.5 \mathrm{ml}$ of each fraction solution was mixed with 3 ml methanol, $0.2 \mathrm{ml} 10 \% \mathrm{AlCl}_{3}, 0.2 \mathrm{ml} 1 \mathrm{M}$ potassium acetate and $5 \mathrm{ml}$ distilled water, and then incubated at room temperature for $30 \mathrm{~min}$. The previous steps were repeated for each of the fractions, after which, absorbance was measured at a wavelength of $415 \mathrm{~nm}$. For a blank control, a working solution was set up with distilled water in place of the sample extract. The samples were prepared in triplicate for each analytic trial, from which the mean and standard deviation values were calculated [22].

\section{Determination of total tannin content (TTC)}

The protocol of Sun et al. was used to determine TTC in the four $R$. rothschildianus leaf fractions, being the most commonly used procedure. Catechin was used as a reference compound to construct a calibration curve. A $100 \mu \mathrm{g} / \mathrm{ml}$ stock in methanol was prepared, from which a dilution series was generated to give catechin concentrations of $10,30,50,70$, and $100 \mu \mathrm{g} / \mathrm{ml}$. A $4 \%$ solution of vanillin in methanol was prepared freshly. Stock solutions of the fractions at $100 \mu \mathrm{g} / \mathrm{ml}$ were prepared using methanol as a solvent. For the working solution, $0.5 \mathrm{ml}$ of each fraction solution was mixed with $3 \mathrm{ml}$ vanillin solution and $1.5 \mathrm{ml}$ of concentrated $\mathrm{HCl}$. The mixture was allowed to stand for $15 \mathrm{~min}$, and then the absorbance at $500 \mathrm{~nm}$ was measured, using a working solution set up with methanol in place of the sample extract as a blank. All working samples were analyzed in triplicate, from which the mean and standard deviation values were calculated. Total tannin in each fraction was expressed in terms of catechin equivalents ( $\mathrm{mg}$ of CAE/g dry weight of leaves) [23].

\section{Antioxidant activity method}

The free 2,2-diphenyl-picrylhydrazyl (DPPH) radical scavenging assay was used to measure antioxidant activity in the different fractions of $R$. rothschildianus leaves. A $1000 \mu \mathrm{g} / \mathrm{ml}$ stock solution of each plant fraction was prepared in methanol. In addition, a $1000 \mu \mathrm{g} / \mathrm{ml}$ solution of trolox was also prepared (the reference standard). A dilution series was prepared from the stock solutions for each fraction, giving six serial dilutions at 2, 5, 10, 20, 50 , and $100 \mu \mathrm{g} / \mathrm{ml}$. One $\mathrm{ml}$ of each extract dilution was mixed with $1 \mathrm{ml} 0.002 \mathrm{~g} / \mathrm{ml} \mathrm{DPPH}$ in methanol. One $\mathrm{ml}$ methanol was added to give a final working volume of 3 
$\mathrm{ml}$. The DPPH solution was freshly prepared, as it was very sensitive to light. The blank control of the series concentrations was DPPH in methanol in a ratio of $1: 2$, without the addition of an extract. All working solutions were incubated at room temperature $\left(25^{\circ} \mathrm{C}\right)$ in the dark for about $30 \mathrm{~min}$. Optical densities were then measured with a spectrophotometer at a wavelength of $517 \mathrm{~nm}$. The following equation was used to calculate \% DPPH inhibition for each plant fraction, with trolox as the standard compound:

$$
\text { DPPH inhibition } \%=\left(A_{B}-A_{t s}\right) / A_{B} \times 100 \%
$$

where, $A_{B}$ is the recorded absorbance of the blank solution, and $A_{t s}$ is the recorded absorbance of the tested sample solution [21].

\section{Porcine pancreatic lipase inhibition assay}

Stock solutions of $500 \mu \mathrm{g} / \mathrm{ml}$ were made from each plant fraction in $10 \%$ DMSO. From these, a dilution series of five concentrations of 50,100,200,300, and $400 \mu \mathrm{g} / \mathrm{ml}$ were made. A $1 \mathrm{mg} / \mathrm{ml}$ stock solution of porcine pancreatic lipase in Tris- $\mathrm{HCl}$ buffer was prepared freshly just before use. The substrate, p-nitrophenyl butyrate (PNPB) was prepared by dissolving $20.9 \mathrm{mg}$ in $2 \mathrm{ml}$ acetonitrile.

For each working solution, $0.1 \mathrm{ml}$ porcine pancreatic lipase was mixed with $0.2 \mathrm{ml}$ plant fraction from each member of the dilution series. Tris- $\mathrm{HCl}$ was added to make the final volume of the working solutions $1 \mathrm{ml}$, and they were incubated at $37^{\circ} \mathrm{C}$ for $15 \mathrm{~min}$. After incubation, $0.1 \mathrm{ml} \mathrm{p}$-nitrophenyl butyrate solution was added to each test-tube. The mixture was then incubated for a further $30 \mathrm{~min}$ at $37^{\circ} \mathrm{C}$. Pancreatic lipase activity was determined by measuring the hydrolysis of PNPB into pnitrophenolate at $410 \mathrm{~nm}$, using a UV spectrophotometer. The same procedure was repeated using orlistat as a standard reference compound. Percentage lipase inhibition by plant fractions was calculated with the following equation:

\section{Lipase inhibition $\%=\left(A_{B}-A_{t s}\right) / A_{B} \times 100 \%$}

where, $A_{B}$ is the recorded absorbance of the blank solution, and $A_{t s}$ is the recorded absorbance of the tested sample solution [24].

\section{a-Amylase inhibitory assay}

A100 mg of each fraction was dissolved in a few milliliters of $10 \%$ DMSO, and then further dissolved up to $100 \mathrm{ml}$ in $0.02 \mathrm{M} \mathrm{Na}_{2} \mathrm{HPO}_{4} / \mathrm{NaH}_{2} \mathrm{PO}_{4}, 0.006 \mathrm{M} \mathrm{NaCl}$, $\mathrm{pH} 6.9$ to give finally stock solutions with concentrations of $1000 \mu \mathrm{g} / \mathrm{ml}$. From these, the following dilutions were prepared of $10,50,70,100$, and $500 \mu \mathrm{g} / \mathrm{ml}$, using $10 \%$ DMSO as the diluent. A $0.2 \mathrm{ml}$ volume of 2 units $/ \mathrm{ml}$ porcine pancreatic $\alpha$-amylase was mixed with $0.2 \mathrm{ml}$ plant fraction and was incubated for $10 \mathrm{~min}$ at $30^{\circ} \mathrm{C}$. After incubation, $0.2 \mathrm{ml}$ of a freshly prepared $1 \%$ starch solution in water was added, and the tubes were then incubated for at least three more minutes. At this point, the reaction was stopped by the addition of $0.2 \mathrm{ml} \mathrm{3,5-}$ dinitro salicylic acid (DNSA) color reagent and was diluted with $5 \mathrm{ml}$ of distilled water, before being heated at $90^{\circ} \mathrm{C}$ for $10 \mathrm{~min}$ in a water bath. The mixture was then cooled to room temperature, and the absorbance was measured at $540 \mathrm{~nm}$. The blank control was prepared using the same quantities described above, but replacing the plant fraction with $0.2 \mathrm{ml}$ buffer. Acarbose was used as a standard reference following the procedure described above. $\alpha$-amylase inhibitory activity was calculated using the following equation:

$$
\text { \%of } \alpha \text {-amylase inhibition }=\left(\mathrm{A}_{\mathrm{B}}-\mathrm{A}_{\mathrm{T}}\right) / \mathrm{A}_{\mathrm{B}} \times 100 \%,
$$

where, $A_{B}$ : is the absorbance of the blank sample, and $\mathrm{A}_{\mathrm{T}}$ is the absorbance of the test sample [25].

\section{a-Glucosidase inhibitory assay}

A dilution series of fractions was made, to yield concentrations of $100,200,300,400$, and $500 \mathrm{mg} / \mathrm{ml}$. The reaction mixtures contained $0.1 \mathrm{ml} 1 \mathrm{U} / \mathrm{ml} \alpha$-glucosidase solution mixed with $0.2 \mathrm{ml}$ of an extract dilution and 0.5 $\mathrm{ml} 100 \mathrm{mM}$ phosphate buffer, $\mathrm{pH} 6$. 8. The mixtures were incubated at $37^{\circ} \mathrm{C}$ for $15 \mathrm{~min}$. Then, $0.2 \mathrm{ml} 5 \mathrm{mM}$ $p$-nitrophenyl $\alpha$-D-galactopyranoside PNPG was added to the reaction mixture and incubated was extended for a further $20 \mathrm{~min}$ at $37^{\circ} \mathrm{C}$. The reaction was terminated by adding $0.1 \mathrm{M} \mathrm{Na}_{2} \mathrm{CO}_{3}$. The absorbance was recorded at a wavelength of $405 \mathrm{~nm}$ for all samples. Acarbose was used as a positive control at the same concentrations as the plant extracts. The results were expressed as percentage inhibition according to the following equation:

$$
\begin{gathered}
\alpha \text { - Glucosidase Inhibition (\%) } \\
=\left(A_{B}-A_{S} / A_{B}\right) \times 100 \%
\end{gathered}
$$

where, $A_{B}$ is the absorbance without enzyme inhibitor, and $A_{S}$ is the absorbance in the presence of the enzyme inhibitor [26].

\section{Cell lines and MTS assay}

HeLa and MCF7 cancer cell lines were obtained from ATCC, the cells were cultured in RPMI-1640 media supplemented with $10 \%$ fetal bovine serum, $1 \%$ penicillin/ streptomycin antibiotics, and $1 \% \mathrm{~L}$-glutamine. Cells were grown in a humidified atmosphere with $5 \% \mathrm{CO}_{2}$ at $37^{\circ} \mathrm{C}$. Cells were seeded at $2.6 \times 10^{4}$ cells/well in a 96well plate. After $48 \mathrm{~h}$, cells were confluent, the media was changed. Cells were then incubated with different leaf fraction concentrations ranging from $0.25-10 \mathrm{mg} / \mathrm{ml}$ of $R$. rothschildianus for $24 \mathrm{~h}$. Cell viability was assessed 
Table 1 Phytochemical screening assessment of $R$. rothschildianus leaves four solvents fractions

\begin{tabular}{|c|c|c|c|c|}
\hline Phytochemically active constituent & Hexane extract & Acetone extract & Methanol extract & Aqueous extract \\
\hline Protein & - & - & + & ++ \\
\hline Reducing sugars & - & - & - & - \\
\hline Complex polysaccharides & - & - & + & - \\
\hline Phenols & ++ & +++ & + & + \\
\hline Starch & - & - & - & +++ \\
\hline Tannins & + & + & - & - \\
\hline Flavonoids & +++ & +++ & ++ & + \\
\hline Saponins & - & - & - & ++ \\
\hline Glycosides & + & - & - & - \\
\hline Terpenoids and steroids & + & - & - & - \\
\hline Alkaloids & - & - & - & - \\
\hline Volatile oil & - & - & - & - \\
\hline
\end{tabular}

with the CellTilter $96^{\circ}$ Aqueous One Solution Cell Proliferation (MTS) Assay according to the manufacturer's instructions (Promega Corporation, Madison, WI). Briefly, at the end of the treatment, $20 \mu \mathrm{l}$ MTS solution per $100 \mu \mathrm{l}$ media was added to each well and incubated at $37^{\circ} \mathrm{C}$ for $2 \mathrm{~h}$. Absorbances were measured at $490 \mathrm{~nm}$ $[27,28]$.

\section{Statistical analysis}

All of the obtained results of the four studied plant fractions (antioxidant, anti-lipase, anti-amylase, antiglycosidase, and cytotoxicity activities) were expressed as mean \pm SD standard deviation; the result was considered significant when the $p$-value was $<0.05$. Data were compared using unpaired $t$-tests.

\section{Results}

\section{Phytochemical screening}

The results of the preliminary phytochemical tests on the $R$. rothschildianus aqueous fractions showed the presence of saponin, phenols, protein, starch, and flavonoids. The methanol extract showed the presence of complex polysaccharides, phenols, protein, and flavonoids, while phenols, tannins, and flavonoids were observed in the acetone fraction, and in hexane fraction phenols, tannins, and flavonoids, glycosides, terpenoids, and steroids were identified as shown in Table 1. However, for the extraction process, methanol showed the highest percentage yield at $29.4 \%$, followed by the acetone fraction with $16.5 \%$. The aqueous extraction yielded $10.6 \%$, while the lowest yield $(7.3 \%)$ was in hexane fraction (Table 2).

\section{Quantitative analysis of TPC, TFC, and TTC}

For the evaluation of TPC, TFC, and TTC, the absorption (Abs) values of several concentrations of the gallic acid, rutin acid, and catechin standards (STDs) were obtained, and regarding these points, three equations were obtained for each STD versus its concentrations to calculate the total phenol, flavonoid, and tannin contents of the hexane, acetone, methanol, and aqueous $R$. rothschildianus fractions are presented in Table 3.

\section{Antioxidant activity}

The results of assessing the free radical scavenging activity of four fractions from $R$. rothschildianus leaves, using trolox as a potent antioxidant standard reference, were expressed as percentage DPPH inhibition (Fig. 1 and Table 4). Therefore, $R$. rothschildianus leaves could be considered an herbal source for antioxidants, and for the acetone fraction, which showed an $\mathrm{IC}_{50}$ value of $6.3 \pm$ $0.4 \mu \mathrm{g} / \mathrm{ml}$. Similar results were also obtained for the hexane fraction, which had an $\mathrm{IC}_{50}$ value of $7.9 \pm 1.3 \mu \mathrm{g} / \mathrm{ml}$ (Table 4). The results were compared to trolox, a potent antioxidant compound, with an $\mathrm{IC}_{50}$ equal to $3.1 \pm$ $0.9 \mu \mathrm{g} / \mathrm{ml}$. By contrast, the aqueous fraction only showed moderate antioxidant activity, with a higher $\mathrm{IC}_{50}$ value of $19.9 \pm 0.7 \mu \mathrm{g} / \mathrm{ml}$, while the methanol extract was inactive in this assay.

\section{Lipase inhibition activity}

In this assay, the anti-obesity activity of fractions from $R$. rothschildianus leaves extract was compared to that of

Table 2 The percentage yield of $R$. rothschildianus leave's fractions

\begin{tabular}{llll}
\hline Fraction & Extract $(\mathbf{g})$ & Plant material $(\mathbf{g})$ & Yield \\
\hline Hexane & 1.82 & 25 & $7.28 \%$ \\
Acetone & 4.12 & 25 & $16.48 \%$ \\
Methanol & 7.35 & 25 & $29.40 \%$ \\
Aqueous & 2.66 & 25 & $10.64 \%$ \\
\hline
\end{tabular}


Table 3 Quantitation of phenols, tannins, and flavonoids in hexane, acetone, methanol, and aqueous fractions of $R$. rothschildianus leaves

\begin{tabular}{llll}
\hline $\begin{array}{l}\text { Leaf } \\
\text { Fractions }\end{array}$ & $\begin{array}{l}\text { Total flavonoids content (TFC), } \mathbf{m g} \text { of RUE/g } \\
\text { leaf dry weight, } \mathbf{\pm} \text { SD }\end{array}$ & $\begin{array}{l}\text { Total phenol content (TPC), } \mathbf{m g} \text { of } \\
\text { GAE/g leaf dry weight, } \pm \text { SD }\end{array}$ & $\begin{array}{l}\text { Total Tannin content (TTC), mg of } \\
\text { CAE/g leaf dry weight, } \pm \text { SD }\end{array}$ \\
\hline Hexane & $92.35 \pm 2.33$ & $17.66 \pm 1.56$ & $2.21 \pm 0.01$ \\
Acetone & $107.30 \pm 4.60$ & $28.20 \pm 0.78$ & $4.95 \pm 0.77$ \\
Methanol & $55.65 \pm 2.33$ & $5.44 \pm 1.56$ & - \\
Aqueous & $32.30 \pm 2.35$ & $1.89 \pm 1.25$ & - \\
\hline
\end{tabular}

orlistat, a potent lipase inhibitory agent (Fig. 2 and Table 4). R. rothschildianus leaves were an excellent alternative natural source of lipase inhibitory agents. The acetone fraction showed an $\mathrm{IC}_{50}$ value of $26.3 \pm 0.6 \mu \mathrm{g} /$ $\mathrm{ml}$, which was very close to that of the reference compound orlistat $(12.3 \pm 0.3 \mu \mathrm{g} / \mathrm{ml})$. Hexane and methanol fractions only recorded moderate $\mathrm{IC}_{50}$ values, equal to $39.8 \pm 0.3 \mu \mathrm{g} / \mathrm{ml}$ and $60.3 \pm 0.4 \mu \mathrm{g} / \mathrm{ml}$, respectively; while the aqueous fraction was inactive.

\section{a-Amylase inhibition activity}

In this assay, the anti-amylase activity of fractions from $R$. rothschildianus leaves extract was compared to that of acarbose, a potent $\alpha$-amylase inhibitory agent (Fig. 3). The acetone fraction was the most potent inhibitor of $\alpha$ amylase, with an $\mathrm{IC}_{50}$ of $19.0 \pm 0.7 \mu \mathrm{g} / \mathrm{ml}$, compared to $28.8 \pm 1.2 \mu \mathrm{g} / \mathrm{ml}$ for acarbose, the reference compound. This suggested that $R$. rothschildianus might be a powerful herbal remedy for diabetes. The aqueous fraction only showed moderate activity in this assay with an $\mathrm{IC}_{50}$ value of $45.7 \pm 0.3 \mu \mathrm{g} / \mathrm{ml}$, while hexane had an $\mathrm{IC}_{50}$ value of $354.8 \pm 1.2 \mu \mathrm{g} / \mathrm{ml}$. The methanol fraction was inactive against the $\alpha$-amylase enzyme. $\mathrm{IC}_{50}$ values were calculated for the four fractions (Table 4).

\section{a-Glucosidase inhibition activity}

Results for $\alpha$-glucosidase were compared with those for acarbose, a strong enzyme inhibitory agent, and $\mathrm{IC}_{50}$ values were calculated for the four fractions (Table 4 and Fig. 4). The acetone fraction exerted the greatest inhibitory action on $\alpha$-glucosidase with an $\mathrm{IC}_{50}$ of $54.9 \pm$ $0.3 \mu \mathrm{g} / \mathrm{ml}$, compared with that of acarbose, the reference compound, at $37.1 \pm 0.3 \mu \mathrm{g} / \mathrm{ml}$. By contrast, the methanol extract fraction showed only moderate inhibition of $\alpha$-glucosidase, with an $\mathrm{IC}_{50}$ of $251.2 \pm 0.4 \mu \mathrm{g} / \mathrm{ml}$, while the hexane and aqueous fractions were inactive in this assay.

\section{Anti-proliferative activity}

The results of treatment of HeLa and MCF7 cancer cells with five different concentrations in $\mathrm{mg} / \mathrm{ml}$ for different extracts showed that the activity against the HeLa cancer cell line was better than against the MCF7 cancer cell line. However, hexane extract was the most potent

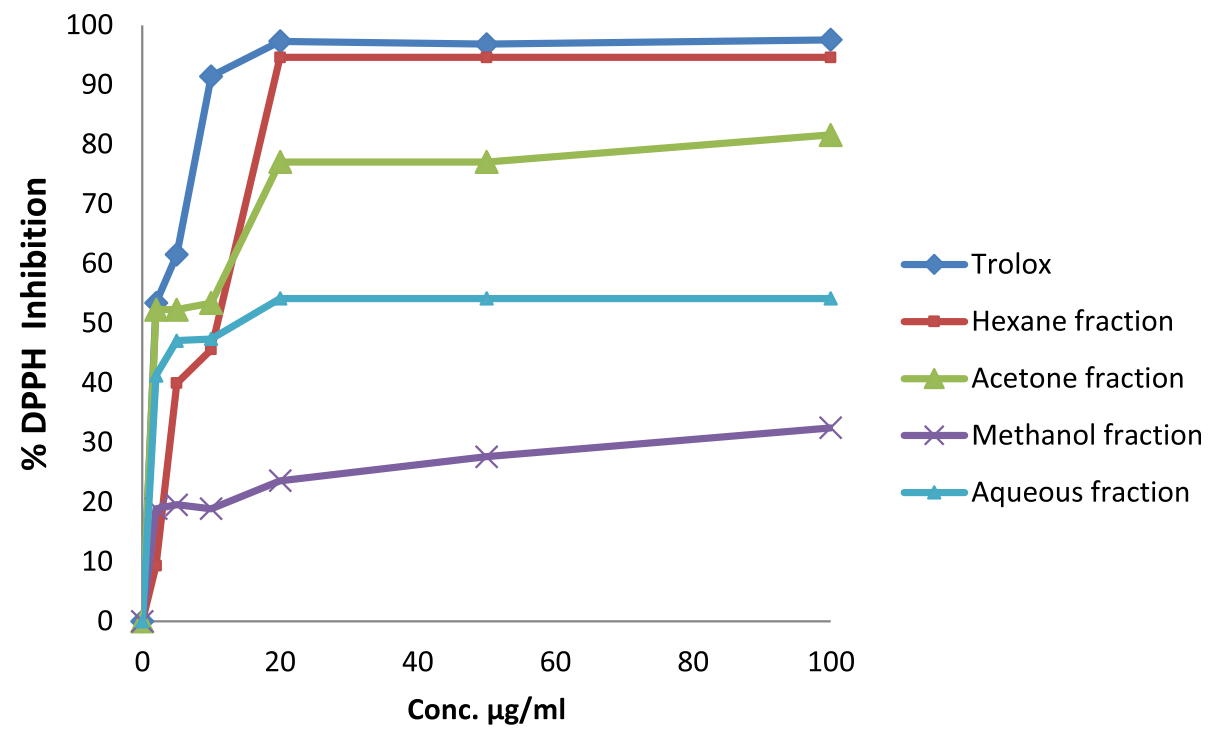

Fig. $1 \%$ Inhibition of DPPH for standard trolox and fractions from R. rothschildianus leaves 
Table 4 The $I_{50}$ for different extracts fractions against DPPH, Lipase, a-Amylase and a-glucosidase in comparison of IC 50 of positive controls

\begin{tabular}{lllllll}
\hline & Target enzyme & Reference & Hexane fraction & Acetone fraction & Methanol fraction & Aqueous fraction \\
\hline $\mathrm{IC}_{50}(\mu \mathrm{g} / \mathrm{mL})$ & $\mathrm{DPPH}$ & $3.10 \pm 0.92^{\mathrm{a}}$ & $7.90 \pm 1.32$ & $6.30 \pm 0.43$ & $\mathrm{Nl}$ & $19.95 \pm 0.71$ \\
& Lipase & $12.30 \pm 0.33^{\mathrm{b}}$ & $39.81 \pm 0.27$ & $26.30 \pm 0.57$ & $60.26 \pm 0.42$ & $\mathrm{Nl}$ \\
& a-Amylase & $28.84 \pm 1.22^{\mathrm{c}}$ & $354.8 \pm 1.17$ & $19.05 \pm 0.75$ & $\mathrm{Nl}$ & $45.70 \pm 0.26$ \\
& a-Glucosidase & $37.15 \pm 0.33^{\mathrm{C}}$ & $\mathrm{Nl}$ & $54.90 \pm 0.33$ & $251.18 \pm 0.43$ & $\mathrm{Nl}$ \\
\hline
\end{tabular}

${ }^{\mathrm{a}}$ Trolox, ${ }^{\mathrm{b}}$ Orlistat, ${ }^{\mathrm{c}}$ Acarbose, Nl: no inhibition (inhibition at conc. higher than $400 \mu \mathrm{g} / \mathrm{ml}$ )

extract at $4 \mathrm{mg} / \mathrm{ml}$ concentration with inhibition percentage 98.9 and $97.4 \%$ against HeLa and MCF7 cancer cell lines, respectively, while methanol extract at the same concentration showed potent activity against HeLa and MCF7 cancer cell lines with 97.2 and 95.6\% inhibition percentage. HeLa cell percentage inhibition on exposure to fractions from $R$. rothschildianus leaves was documented, compared to the positive control doxorubicin (Fig. 5a). MCF7 cells percentage inhibition was similarly determined for the four fractions from $R$. rothschildianus leaves, compared to the control (Fig. 5b).

\section{Discussion}

The DPPH radical scavenging assay is well known as a simple method for detecting antioxidant capacity in compounds. DPPH is a stable free radical that gives a purple color in alcohol solutions, and on reduction in the presence of hydrogen donating antioxidants, turns the solution colorless [29]. Therefore, $R$. rothschildianus leaves could be considered a natural source for antioxidants, especially for the acetone fraction, which showed an $\mathrm{IC}_{50}$ value of $6.3 \pm 0.4 \mu \mathrm{g} / \mathrm{ml}$. Similar results were also obtained for the hexane fraction, which had an $\mathrm{IC}_{50}$ value of $7.9 \pm 1.3 \mu \mathrm{g} /$ $\mathrm{ml}$ (Table 4). The results were compared to trolox, a potent antioxidant compound, with an $\mathrm{IC}_{50}$ equal to $3.1 \pm$ $0.9 \mu \mathrm{g} / \mathrm{ml}$. By contrast, the aqueous fraction only showed moderate antioxidant activity, with a higher $\mathrm{IC}_{50}$ value of $19.9 \pm 0.7 \mu \mathrm{g} / \mathrm{ml}$, while the methanol extract was inactive in this assay. These results were consistent with the presence of phenols and flavonoids in the plant, a powerful scavenger source for free radicals as shown with DPPH in this study. These results were in line with the diversity of phenolic compounds in plants, simple phenols like gallic acid, and more sophisticated phenolic acids like anthocyanins, hydroxyl cinnamic acid derivatives, and flavonoids. All these classes of compounds have received extensive attention due to their multiple physiological functions, especially free radical scavenging, anti-mutagenic, antiinflammatory, and anti-carcinogenic activities [30]. As listed in Table 3, the acetone extract recorded the highest content of both phenolic compounds and flavonoids, $28.2 \pm 0.8 \mathrm{mg}$ of $\mathrm{GAE} / \mathrm{g}$ and $107.3 \pm 4.6 \mathrm{mg}$ of $\mathrm{RU} / \mathrm{g}$, respectively. A previous report on some Rumex species found phenolic compounds in an ethanol extract from leaves of Rumex vesicarius L., which were possibly involved in free radical reactions, reducing the stable used DPPH radical to a yellowish colored diphenyl picrylhydrazine derivative from its original violet color [31].

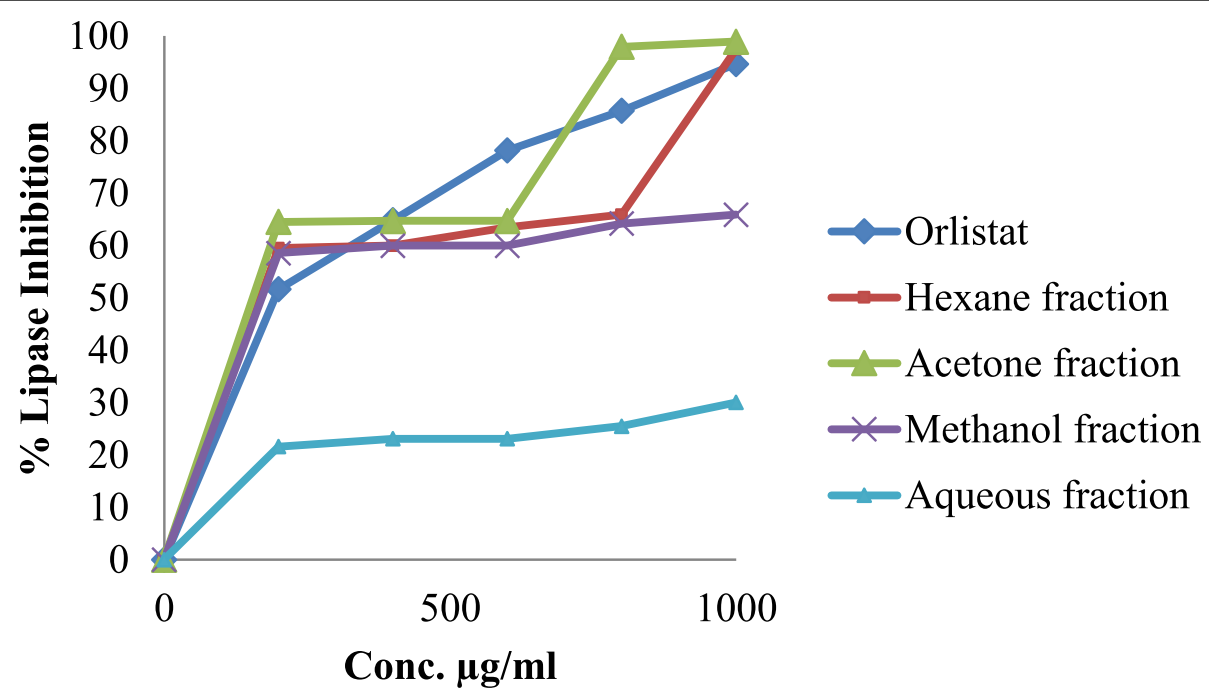

Fig. $2 \%$ Inhibition of lipase by standard orlistat and fractions from $R$. rothschildianus leaves 


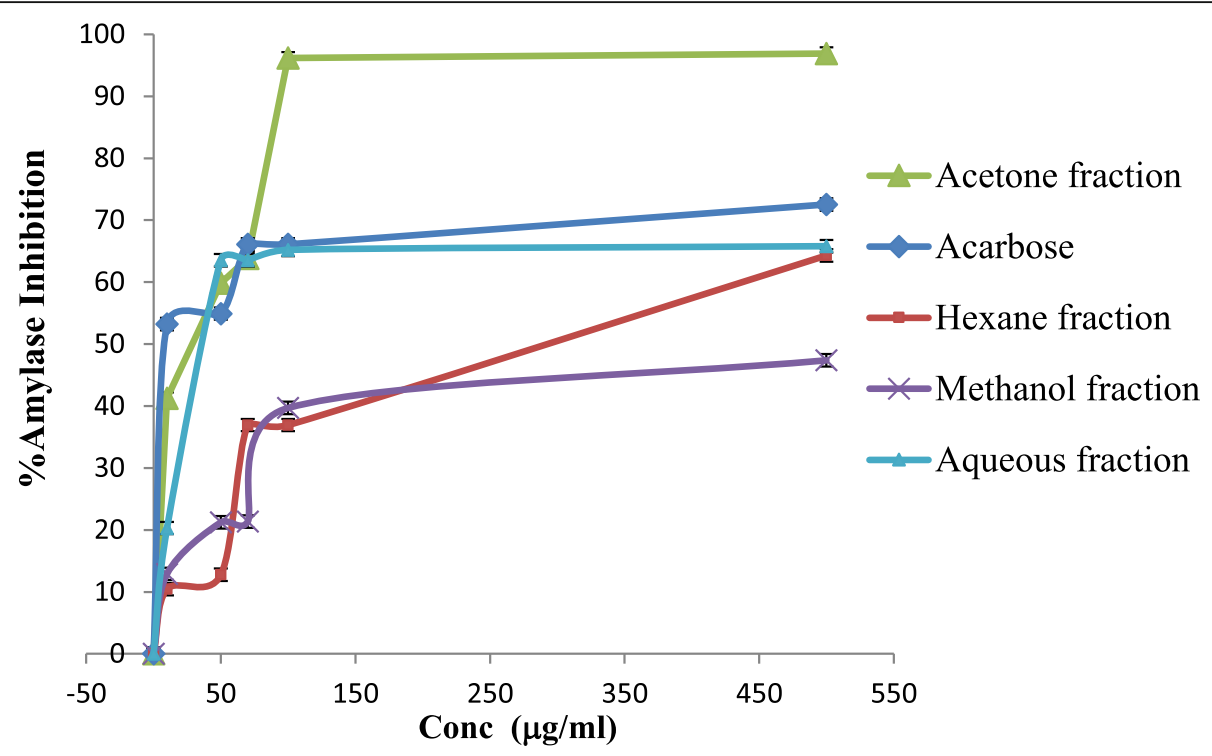

Fig. 3 a-Amylase inhibition percentage of fractions from $R$. rothschildianus leaves compared to acarbose (standard compound)

R. rothschildianus leaves were an excellent alternative natural source of lipase inhibitory agents. The acetone fraction showed an $\mathrm{IC}_{50}$ value of $26.3 \pm 0.6 \mu \mathrm{g} / \mathrm{ml}$, which was very close to that of the reference compound orlistat $(12.3 \pm 0.3 \mu \mathrm{g} / \mathrm{ml})$. Hexane and methanol fractions only recorded moderate $\mathrm{IC}_{50}$ values, equal to $39.8 \pm 0.3 \mu \mathrm{g} / \mathrm{ml}$ and $60.3 \pm 0.4 \mu \mathrm{g} / \mathrm{ml}$, respectively; while the aqueous fraction was inactive. Pancreatic lipase is a major enzyme involved in enterocyte triglyceride absorption. Therefore, its inhibition represents an important strategy in the management of obesity [32]. Plants rich in phenolic compounds have been screened in several reports for anti-lipase activity. Lipase inhibitory activity ranging from 40 to $>70 \%$ has been found by in vitro tests in many different families, including Solanaceae (Solanum tuberosum), Brassicaceae (Brassica nigra and Raphanus sativus), Rosaceae (Malus domestica Borkh. and Filipendula ulmaria (L.) Maxim.), Ericaceae (Arctostaphylos uva-ursi (L.) Spreng. and

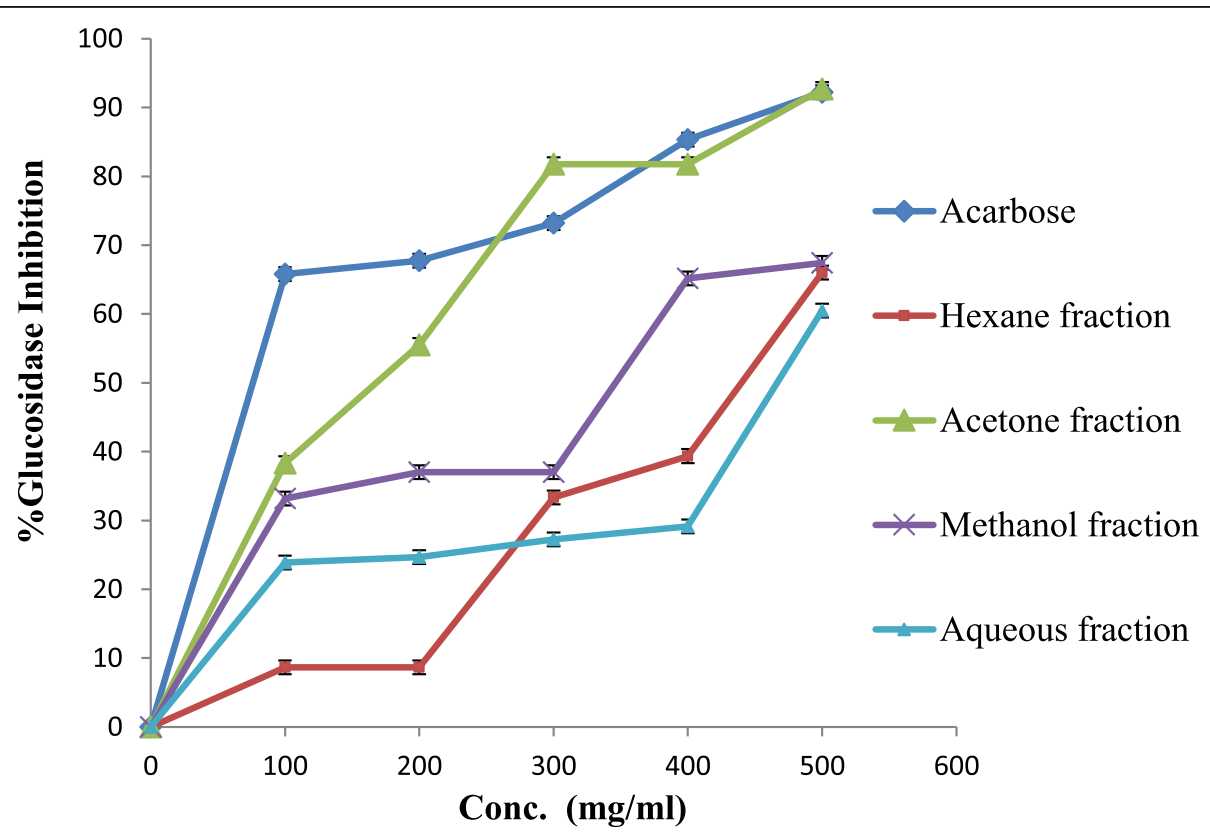

Fig. 4 a-glucosidase inhibition percentage of fractions from $R$. rothschildianus leaves compared to acarbose 


\section{A) Hela Cancer Cell Line}

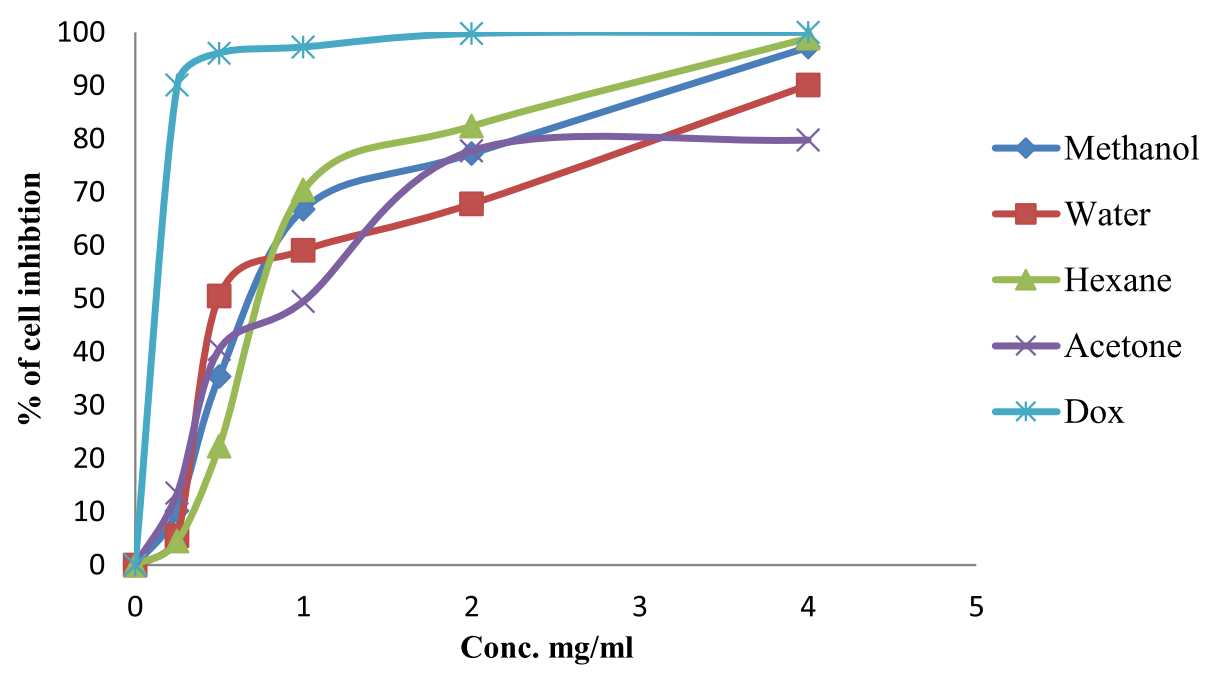

B) MCF7 Cancer Cell Line

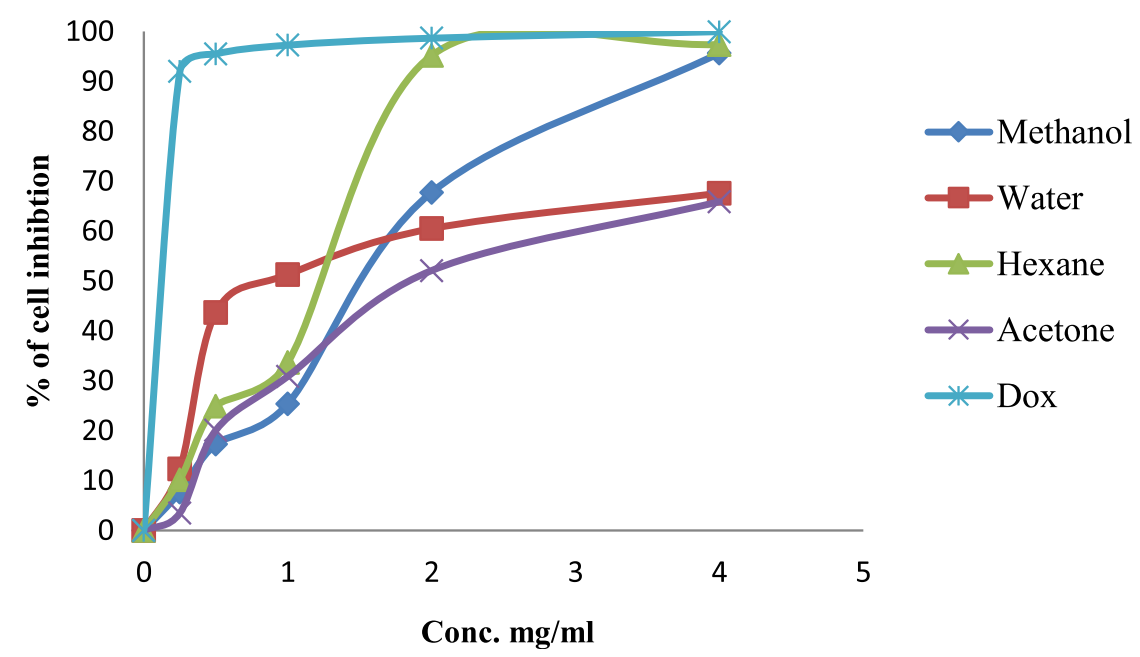

Fig. 5 a HeLa Cancer cell line percentage inhibition by fractions from R. rothschildianus leaves, compared to the positive control (Dox). b MCF7 Cancer cell line percentage inhibition by fractions from $R$. rothschildianus leaves, compared to the positive control (Dox)

Vaccinium myrtillus L.), and Fabaceae (Pisum sativum L. and Phaseolus vulgaris L.) [33].

The acetone fraction was the most potent inhibitor of $\alpha$-amylase, with an $\mathrm{IC}_{50}$ of $19.0 \pm 0.7 \mu \mathrm{g} / \mathrm{ml}$, compared to $28.8 \pm 1.2 \mu \mathrm{g} / \mathrm{ml}$ for acarbose, the reference compound. This suggested that $R$. rothschildianus might be a powerful herbal remedy for diabetes. The aqueous fraction only showed moderate activity in this assay with an $\mathrm{IC}_{50}$ value of $45.7 \pm 0.3 \mu \mathrm{g} / \mathrm{ml}$, while hexane had an $\mathrm{IC}_{50}$ value of $354.8 \pm 1.2 \mu \mathrm{g} / \mathrm{ml}$. The methanol fraction was inactive against $\alpha$-amylase. A possible explanation for the aqueous fraction being a good enzyme inhibitor was the presence of saponins. Earlier scientific investigations found that saponins were bioactive against diabetes [34]. The potent effect of the acetone extract fraction against amylase might be due to the high content of both phenolic compounds and flavonoids. Corchorus olitorius exerts $\alpha$-amylase and $\alpha$-glucosidase inhibitory effects due to constituents, especially phenolic compounds like caffeic acid [35].

The acetone fraction exerted the greatest inhibitory action on $\alpha$-glucosidase with an $\mathrm{IC}_{50}$ of $54.9 \pm 0.3 \mu \mathrm{g} / \mathrm{ml}$, compared with that of acarbose, the reference compound, at $37.1 \pm 0.3 \mu \mathrm{g} / \mathrm{ml}$. By contrast, the methanol extract fraction showed only moderate inhibition of $\alpha$ glucosidase, with an $\mathrm{IC}_{50}$ of $251.2 \pm 0.4 \mu \mathrm{g} / \mathrm{ml}$, while the 
hexane and aqueous fractions were inactive in this assay. The third category of oral hypoglycemic agents includes $\alpha$-glucosidase inhibitors. There are a variety of $\alpha$ glucosidase inhibitors, such as acarbose and voglibose, which usually are found in plant sources. They show valuable stabilization of blood glucose levels after a meal and have been used clinically in the management of diabetes mellitus [36, 37].

The results of treatment of both cancer cells (HeLa and MCF7) with various concentrations in $\mathrm{mg} / \mathrm{ml}$ for different extracts showed that the general activity against the HeLa cancer cell line was better than MCF7 cancer cell line. The hexane extract showed potent anticancer activity at $4 \mathrm{mg} / \mathrm{ml}$ concentration with inhibition percentage 98.9 and $97.4 \%$ against HeLa and MCF7 cancer cell lines, respectively, while methanol extract at the same concentration showed potent activity against HeLa and MCF7 cancer cell lines with 97.2 and 95.6\% inhibition percentage. From the previous results, the hexane fraction exerted a significant cytotoxic effect on both HeLa and MCF7 cell, with inhibition percentages reaching 99 and $92.4 \%$ at $4 \mathrm{mg} / \mathrm{ml}$ of hexane fraction concentration, respectively. This was consistent with the cytotoxic effects of both terpenoids and steroids, which were found in the hexane fraction. Diosgenin, a naturally occurring steroid and triterpenoids found in some plants, has been shown to inhibit breast cancer $[38,39]$.

\section{Conclusion}

The results from this study on $R$. rothschildianus leaves indicated that the acetone extract fraction had significant potential in providing phytotherapies for diabetes and obesity, based on its potent inhibition of lipase, $\alpha$ amylase, and $\alpha$-glucosidase. In addition, the acetone fraction also showed a significant free radical scavenging activity. On the other hand, the hexane fraction showed significant inhibition of both HeLa and MCF7 cell lines, which might be related to its high content of terpenes and steroids. These observations in this study might lead to further in vivo studies to develop new natural pharmaceutical formulations effective in the treatment of obesity, diabetes mellitus, and some cancers.

\footnotetext{
Abbreviations

PNPB: p-nitrophenyl butyrate; DNSA: 3,5-dinitrosalicylic acid; DMSO: Dimethyl sulfoxide; DPPH: 2,2-diphenyl-1-picrylhydrazyl; $\mathrm{IC}_{50}$ : Half maximal inhibitory concentration; Trolox: 6-hydroxy-2,5,7,8-tetramethylchroman-2-carboxylic acid; $A_{B}$ : Absorbance of the blank solution; $A_{t s}$ : Absorbance of the tested sample solution; MCF7: Human breast cancer cell line; HeLa: Human cervix adenocarcinoma cell line; CAE: Catechin equivalent; GAE: Gallic acid equivalent; RUE: Rutin equivalent; PNPG: p-nitrophenyl glucopyranoside; Dox: Doxorubicin; Conc: Concentration; TPC: Total phenolic content; TCC: Total tannin content; TFC: Total flavonoid content
}

\section{Acknowledgments}

The authors would like to acknowledge the Faculty of Graduate Studies (Pharmaceutical sciences program) at An-Najah National University.

\section{Authors' contributions}

$\mathrm{NJ}$ designed the project. NJ, GD, and MH performed the experiments, analyzed the data, interpreted the data, drafted and edited the manuscript. All authors read and approved the final draft.

\section{Funding}

None.

Availability of data and materials

The datasets used and/or analyzed during the current study are available from the corresponding author on reasonable request.

\section{Declarations}

Ethics approval and consent to participate Not applicable.

\section{Consent for publication}

The authors of the current work gave constant for publication to Dr. Nidal Jaradat and Dr. Mohammed Hawash.

\section{Competing interests}

The authors declare that they have no competing interests.

Received: 19 November 2020 Accepted: 18 March 2021

Published online: 31 March 2021

\section{References}

1. Hlila MB, Mosbah H, Zanina N, Ben Nejma A, Ben Jannet H, Aouni M, et al. Characterisation of phenolic antioxidants in Scabiosa arenaria flowers by LC-ESI-MS/MS and NMR. J Pharm Pharmacol. 2016;68(7):932-40. https://doi. org/10.1111/jphp.12561.

2. Kumarasingha R, Preston S, Yeo T-C, Lim DS, Tu C-L, Palombo EA, et al. Anthelmintic activity of selected ethno-medicinal plant extracts on parasitic stages of Haemonchus contortus. Parasit Vectors. 2016;9(1):1-7.

3. Barry H. Antioxidant effects a basis for drug selection. Drugs. 1991;42(2):569605.

4. Davis PH. Flora of Turkey and the East Aegean Islands; 1970.

5. Ulukanli Z, Ulukanli S, Ozbay H, Ilcim A, Tuzcu M. Antimicrobial activities of some plants from the eastern Anatolia region of Turkey. Pharm Biol. 2005; 43(4):334-9. https://doi.org/10.1080/13880200590951757.

6. Ozturk S, Ozturk A. Antibacterial activity of aqueous and methanol extracts of Rumex alpinus. and Rumex caucasicus. Pharm Biol. 2007:45(2):83-7. https://doi.org/10.1080/13880200601105285

7. Abdel-Sattar E, Harraz FM, El Gayed SH. Antimicrobial activity of extracts of some plants collected from the Kingdom of Saudi Arabia. J King Abdulaziz Univ Med Sci. 2008;15(1):25-33. https://doi.org/10.4197/Med.15-1.3.

8. Tiwari R, Sinha K. Chemical examination of rumex-hastatus d-don, Council scientific \& industrial res anusandhan bhawan, 2 rafi marg, new; 1980. p. $531-2$.

9. Lapane KL, Yang S, Driban JB, Liu SH, Dubé CE, McAlindon TE, et al. Effects of prescription nonsteroidal antiinflammatory drugs on symptoms and disease progression among patients with knee osteoarthritis. Arthritis Rheum. 2015;67(3):724-32. https://doi.org/10.1002/art.38933.

10. Jaradat N, Qneibi M, Hawash M, Sawalha A, Qtaishat S, Hussein F, et al. Chemical composition, antioxidant, antiobesity, and antidiabetic effects of helichrysum sanguineum (L.) Kostel. from Palestine. Arab J Sci Eng. 2020:1-11.

11. Zhang H-Z, Kasibhatla S, Kuemmerle J, Kemnitzer W, Ollis-Mason K, Qiu L, et al. Discovery and structure- activity relationship of 3-aryl-5-aryl-1, 2, 4-oxadiazoles as a new series of apoptosis inducers and potential anticancer agents. J Med Chem. 2005;48(16):5215-23. https://doi.org/10.1021/jm050292k.

12. Hawash M, Baytas S. Antiproliferative activities of some biologically important scaffold. FABAD J Pharm Sci. 2017;43(1):59-77.

13. Hawash MM, Kahraman DC, Eren F, Cetin Atalay R, Baytas SN. Synthesis and biological evaluation of novel pyrazolic chalcone derivatives as novel hepatocellular carcinoma therapeutics. Eur J Med Chem. 2017;129:12-26. https://doi.org/10.1016/j.ejmech.2017.02.002.

14. Hawash M. Highlights on specific biological targets; cyclin-dependent kinases, epidermal growth factor receptors, ras protein, and cancer stem cells in anticancer drug development. Drug Res. 2019. 
15. Joseph B, Raj SJ. Pharmacognostic and phytochemical properties of aloe vera linn an overview. Int J Pharm Sci Rev Res. 2010;4(2):106-10.

16. Jaradat NA, Al-lahham S, Zaid AN, Hussein F, Issa L, Abualhasan MN, et al. Carlina curetum plant phytoconstituents, enzymes inhibitory and cytotoxic activity on cervical epithelial carcinoma and colon cancer cell lines. Eur J Integr. 2019;30:100933. https://doi.org/10.1016/j.eujim.2019.100933.

17. Chan $\mathrm{C}-\mathrm{H}$, Ngoh G-C, Yusoff R. A brief review on anti diabetic plants: global distribution, active ingredients, extraction techniques and acting mechanisms. Pharmacogn Rev. 2012;6(11):22. https://doi.org/10.4103/09737847.95854 .

18. Bourgaud F, Gravot A, Milesi S, Gontier E. Production of plant secondary metabolites: a historical perspective. Plant Sci. 2001;161(5):839-51. https:// doi.org/10.1016/S0168-9452(01)00490-3.

19. Iqbal E, Salim KA, Lim LB. Phytochemical screening, total phenolics and antioxidant activities of bark and leaf extracts of Goniothalamus velutinus (airy Shaw) from Brunei Darussalam. J King Saud Univ Sci. 2015;27(3):224-32. https://doi.org/10.1016/j.jksus.2015.02.003.

20. Hawash M, Jaradat N, Elaraj J, Hamdan A, Lebdeh SA, Halawa T. Evaluation of the hypoglycemic effect of seven wild folkloric edible plants from Palestine: (Antidiabetic effect of seven plants from Palestine). J Altern Complement Med. 2019;17(1).

21. Cheung L, Cheung PC, Ooi VE. Antioxidant activity and total phenolics of edible mushroom extracts. Food Chem. 2003;81(2):249-55. https://doi.org/1 0.1016/S0308-8146(02)00419-3

22. Chang C-C, Yang M-H, Wen H-M, Chern J-C. Estimation of total flavonoid content in propolis by two complementary colometric methods. J Food Drug Anal. 2002;10(3):3.

23. Sun B, Ricardo-da-Silva JM, Spranger I. Critical factors of vanillin assay for catechins and proanthocyanidins. J Agric Food Chem. 1998;46(10):4267-74. https://doi.org/10.1021/jf980366j.

24. Drent M, Larsson I, William-Olsson T, Quaade F, Czubayko F, Von Bergmann K, et al. Orlistat (Ro 18-0647), a lipase inhibitor, in the treatment of human obesity: a multiple dose study. Int J Obes Relat Metab Disord. 1995;19(4):221.

25. Sudha P, Zinjarde SS, Bhargava SY, Kumar AR. Potent a-amylase inhibitory activity of Indian Ayurvedic medicinal plants. BMC Complement Altern Med. 2011;11(1):5

26. Ademiluyi $\mathrm{AO}$, Oboh $\mathrm{G}$. Soybean phenolic-rich extracts inhibit key-enzymes linked to type 2 diabetes (a-amylase and a-glucosidase) and hypertension (angiotensin I converting enzyme) in vitro. Exp Toxicol Pathol. 2013;65(3): 305-9. https://doi.org/10.1016/j.etp.2011.09.005.

27. Hawash M, Jaradat N, Hameedi S, Mousa A. Design, synthesis and biological evaluation of novel benzodioxole derivatives as COX inhibitors and cytotoxic agents. BMC Chem. 2020;14(1):1-9.

28. Jaradat N, Hawash M, Murad NA. Synthesis and biological evaluation of benzodioxol derivatives as cyclooxygenase inhibitors. Lett Drug Des Discov. 2020;17(1).

29. Garcia EJ, Oldoni TLC, Alencar SM, Reis A, Loguercio AD, Grande RHM. Antioxidant activity by DPPH assay of potential solutions to be applied on bleached teeth. Braz Dent J. 2012;23(1):22-7. https://doi.org/10.1590/S010364402012000100004

30. Nuengchamnong N, De Jong C, Bruyneel B, Niessen W, Irth H, Ingkaninan K. HPLC coupled on-line to ESI-MS and a DPPH-based assay for the rapid identification of anti-oxidants in Butea superba. Phytochem Anal. 2005;16(6): 422-8. https://doi.org/10.1002/pca.865.

31. Dore CMPG, Alves MGCF, Will LSEP, Costa TG, Sabry DA, de Souza Rêgo LAR, et al. A sulfated polysaccharide, fucans, isolated from brown algae Sargassum vulgare with anticoagulant, antithrombotic, antioxidant and antiinflammatory effects. Carbohydr Polym. 2013;91(1):467-75. https://doi.org/1 0.1016/j.carbpol.2012.07.075.

32. Birari RB, Bhutani KK. Pancreatic lipase inhibitors from natural sources: unexplored potential. Drug Discov Today. 2007;12(19-20):879-89. https:// doi.org/10.1016/j.drudis.2007.07.024.

33. Sharma N, Sharma VK, Seo S-Y. Screening of some medicinal plants for antilipase activity. J Ethnopharmacol. 2005;97(3):453-6. https://doi.org/10.1016/j. jep.2004.11.009.

34. Hamden K, Jaouadi B, Salami T, Carreau S, Bejar S, Elfeki A. Modulatory effect of fenugreek saponins on the activities of intestinal and hepatic disaccharidase and glycogen and liver function of diabetic rats. Biotechnol Bioprocess Eng. 2010;15(5):745-53. https://doi.org/10.1007/s12257-009-3159-0.

35. Oboh G, Ademiluyi AO, Akinyemi AJ, Henle T, Saliu JA, Schwarzenbolz U. Inhibitory effect of polyphenol-rich extracts of jute leaf (Corchorus olitorius) on key enzyme linked to type 2 diabetes (a-amylase and a-glucosidase) and hypertension (angiotensin I converting) in vitro. J Funct Foods. 2012:4(2): 450-8. https://doi.org/10.1016/j.jff.2012.02.003.

36. Playford RJ, Pither C, Gao R, Middleton SJ. Use of the alpha-glucosidase inhibitor acarbose in patients with 'Middleton syndrome': Normal gastric anatomy but with accelerated gastric emptying causing postprandial reactive hypoglycemia and diarrhea. Can J Gastroenterol Hepatol. 2013; 27(7):403-4.

37. Mata R, Cristians S, Escandón-Rivera S, Juárez-Reyes K, Rivero-Cruz I. Mexican antidiabetic herbs: valuable sources of inhibitors of a-glucosidases. J Nat Prod. 2013;76(3):468-83. https://doi.org/10.1021/np300869g.

38. Chiang C-T, Way T-D, Tsai S-J, Lin J-K. Diosgenin, a naturally occurring steroid, suppresses fatty acid synthase expression in HER2-overexpressing breast cancer cells through modulating Akt, mTOR and JNK phosphorylation. FEBS Lett. 2007;581(30):5735-42. https://doi.org/10.1016/j. febslet.2007.11.021.

39. Bishayee A, Ahmed S, Brankov N, Perloff M. Triterpenoids as potential agents for the chemoprevention and therapy of breast cancer. Front Biosci. 2011;16(1):980. https://doi.org/10.2741/3730.

\section{Publisher's Note}

Springer Nature remains neutral with regard to jurisdictional claims in published maps and institutional affiliations.

Ready to submit your research? Choose BMC and benefit from:

- fast, convenient online submission

- thorough peer review by experienced researchers in your field

- rapid publication on acceptance

- support for research data, including large and complex data types

- gold Open Access which fosters wider collaboration and increased citations

- maximum visibility for your research: over $100 \mathrm{M}$ website views per year

At BMC, research is always in progress.

Learn more biomedcentral.com/submissions 